\title{
COMPARATIVE LEGAL RESEARCH ON CONTRACT LAW CHANGES UNDER COVID-19 PANDEMIC: ENGLAND, UNITED STATES, ASIA AND UKRAINE
}

ESTUDIO COMPARADO DE REFORMAS DE LA LEY CONTRACTUAL DURANTE EL COVID-19: INGLATERRA, ESTADOS UNIDOS, ASIA Y UCRANIA

\author{
Inna Vorotyntseva* \\ Ivanna Hranina** \\ Maryna Pysarenko ${ }^{* * *}$
}

\begin{abstract}
The study aims to characterize the changes in contract law under the influence of the Covid-19 pandemic in Ukraine and the world. For this purpose, we used systemic, comparative-legal, and formal-legal methods. The paper consists of an introduction, methodology section, bibliography review, results, discussion, conclusions, and references. In the result of the study some distinctive features of changes in contract law under Covid-19 pandemic at the level of national law of Ukraine and some foreign countries were characterized and highlighted. The authors came to the conclusion that changes in contract law are typical for the countries of continental law. Instead, common law states remain resistant to changes in contract law, particularly, the force-majeure application. The reason for this lies in the specific doctrine of the common law countries, as England and the United States. These countries' courts remain unshakable in terms of managing the contracts performance. In contrast, some Asian and European states (including Ukraine) are characterized by dynamic changes in legislation,
\end{abstract}

\footnotetext{
* Ph.D. candidate, Civil Law Department of National University "Odesa Law Academy" (Odesa, Ukraine). https://orcid.org/0000-0001-9002-3908. tinceva@ukr.net

** Ph.D. candidate, Civil Law Department of National University "Odesa Law Academy" (Odesa, Ukraine). https://orcid.org/0000-0002-3626-269X. ivanna.hranina@gmail.com

*** Ph.D. candidate, Civil Law Department of National University "Odesa Law Academy" (Odesa, Ukraine). https://orcid.org/0000-0002-4711-5249.m.pisarenko160690@gmail.com
} 
given the pandemic situation. The paper also discusses similar institutions like hardship and frustration of purpose, which are both applicable in continental and common law countries.

Keywords: Contract Law, Force Majeure, Contract Performance, Hardship, Frustration of Purpose

Resumen: El estudio tiene como objetivo detectar qué cambios se han dado en la ley de contratos por razón de la pandemia Covid-19 en Ucrania y el mundo. Para ello, utilizamos métodos sistémicos, comparativos-legales y formales-legales. El trabajo consta de una introducción, una sección donde se explica la metodología usada, la revisión de bibliografía, los resultados, la discusión del tema, las conclusiones y las referencias. Como resultado del estudio aparecieron algunas características distintivas de los cambios en la ley de contratos bajo la pandemia de Covid-19 a nivel de la ley nacional de Ucrania y de varios países extranjeros. Los autores llegaron a la conclusión de que los cambios en el derecho contractual son típicos de los países de derecho continental. En cambio, los estados de derecho consuetudinario siguen siendo resistentes a los cambios en el derecho contractual, en particular, a la hora de aplicar la fuerza mayor. La razón de esto radica en la doctrina específica de los países donde impera el derecho consuetudinario, como lo son Inglaterra y Estados Unidos. Los tribunales de estos países siguen siendo inquebrantables en cuanto a la gestión de la ejecución de los contratos. Por el contrario, algunos estados asiáticos y europeos (incluida Ucrania) se caracterizan por cambios dinámicos en la legislación, dada la situación de la pandemia. El estudio también analiza instituciones similares como las dificultades contractuales y la frustración de propósito del contrato, que son aplicables en el derecho continental y el consuetudinario.

Palabras clave: Ley de contratos, fuerza mayor, cumplimiento de los términos contractuales, frustración del fin del contrato

Summary. I. Introduction. II. Methodology. III. Analysis of recent research. IV. Results and discussion. IV.1. Theoretical and Legal Aspects of the Specifics of Changes in Contract Law in a Corona Crisis. IV.2. World Experience. a) England. b) The United States. c) Thailand (Kingdom of Thailand). d) Laws of the Middle East. e) China (People's Republic of China). f) National Legislation of Ukraine. V. Conclusions. References. 


\section{INTRODUCTION}

In late 2019, an outbreak of an unknown disease that caused SARS was recorded in Wuhan, Hubei Province, China (Anand et al., 2020; Lu, Stratton, \& Tang, 2020; Wu, Zhao, Yu, Chen et al., 2020; Zhu, Zhang et al., 2020). All indications are that the root of infection was animals sold on the local market for further consumption (Andersen et al., 2020; Lu, Zhao, Li, Niu, Yang et al., 2020). Later, virologists determined that the cause of the disease, called Covid-19, was a pathogen from the coronavirus family, whose genome was $79 \%$ similar to its predecessor, SARS-CoV, which was responsible for the spread of acute respiratory disease in 2003 (Lu, Zhao, Li, Niu, Yang et al., 2020; Tan, Zhao, Ma et al., 2020). The rapid spread of the new coronavirus SARS-CoV-2 led to the WHO declaring a pandemic on March 11, 2020 (Sohrabi et al., 2020).

This event has significantly affected all spheres of life, both socially and individually (Gostin \& Wiley, 2020). The quarantine restrictions have resulted in declining economic development, rising unemployment, homelessness, rising mortality, and the prevalence of mental disorders in many countries (Grover et al., 2020; Nicola et al., 2020; Serafini et al., 2020; Xiong et al., 2020). There are studies according to which the combination of such factors will negatively affect the formation of gender equality in the future if it has not pushed us back decades in this aspect (Alon et al., 2020). If we take into account the impact of the epidemic on the economy, for which transparent functioning within the legal field is extremely important, it should be noted that quarantine restrictions have become one of the factors that influenced the implementation of changes in the field of contract law, which accompanies a significant part of business operations of both small entrepreneurs (Bartik et al., 2020) and large corporations (McKibbin \& Fernando, 2020). One of the less obvious factors here is the changes that may be made to contracts between individuals because while large companies have legal support departments, legal counsel, the average citizen in a pandemic can fall victim to unfair performance of contracts, abuse of by counterparties, or financial fraud. Therefore, in this aspect, it is necessary to pay attention to the presence of preconditions, or objective factors, for changes in the field of contract law, which will primarily affect ordinary citizens, as well as to analyze how these changes, which are caused by the Covid-19 pandemic, manifest themselves in the legal field. At the same time, it is necessary to note specific cases of the impact of changes in contract law in a pandemic as having a broader meaning than usual force majeure or serve as an exception to general trends, and therefore are of particular interest to legal science. 
At the theoretical level, there is a discussion about the feasibility of recoding the Civil Code of Ukraine (Dovgert, 2019; Kharytonov, 2020). It is pointed out that the pandemic of the new coronavirus will make its adjustments not only to temporary measures designed to help alleviate the problems caused by the epidemic but also to the ideological, starting elements of the entire civil law system, will somehow encourage rethinking outdated norms (Kharytonov \& Kharytonova, 2020ab). On a more general level, this means a revision of the socio-economic system, as there is a problem of balance of private and public interests (Gostin \& Hodge, 2020; Parmet \& Sinha, 2020; Stott, West, \& Harrison, 2020).

The new coronavirus pandemic has confirmed another point of view, namely that no country in a globalized world will be able to shake off the spread of the epidemic by closing its borders. Moreover, own, national, resources will not be enough to counter the spread of the virus. Hence the inevitability of foreign aid, the use of foreign experience. Similarly, in the context of our study, this applies to foreign legal developments, even those legal systems that belong to other legal families. Assuming that the convergence of the legal systems of different countries will only intensify as a result of globalization processes, this argument becomes even more relevant in the future. Therefore, in this aspect, it is necessary to consider the changes that have been made to the contract law of foreign countries under the influence of the coronavirus pandemic.

The issue of recognizing the pandemic, as a force majeure, can be approached from different points of view. Opponents of this approach may argue that, for example, an event constitutes force majeure only if it meets the legal criteria, making it impossible to fulfill the obligation. From this point of view, Covid-19 and the government's response to the epidemic can be a force majeure in certain sectors of the economy (e.g., travel, tourism, etc.), with minimal impact and in some cases even stimulating other areas (IT, web-services, e-commerce, etc.). According to this position, the recognition of Covid-19 as a force majeure will require the establishment of a causal link that made it impossible to fulfill the obligation in each case. Another approach is to recognize Covid-19 as a force majeure in general with all the consequences. However, the controversy remains that for certain types of social relations, the epidemic does not make it impossible to fulfill obligations.

\section{Methodology}

The methodological basis of the study is philosophical, general, and special scientific methods. 
The application of the systematic method made it possible to assess the facts and data in their entirety, mutual influence, and connection, by highlighting the main features of the regulation (of foreign legislation and Ukraine) the issues related to contract law in the context of the coronary crisis. At the research level, this meant distinguishing the main features, principles, ideas, characteristics of the legal system of a particular country, comparing them with the identification of concepts that are common to all countries or at least features that are more often than others repeated as a reaction legislators on the spread of coronavirus Covid-19 in terms of its impact on contractual obligations (i.e., in the system-structural unity of the main factors influencing the spheres of human life). As a result, certain regularities, regarding the specifics of changes in contract law, as well as the nature and impact of individual or similar cases in judicial practice are summarized.

Moreover, the use of the comparative-legal method has been useful in analyzing the differences between national and international norms in the field of contract law under the influence of the Covid-19 pandemic. This was especially useful in comparing the continental legal systems and the law of the Anglo-Saxon legal family, that is, states with a predominance of common case law. Also, with the help of this method, it was possible to identify the main differences and common features of the concept of force majeure, algorithms for their application to contracts in different legal systems. The comparative law method in the context of work is part of a broader complex system method, which was described above. Additionally, the comparative-legal method was used to distinguish the rules of law within the legal system of one country, if it concerns the choice between methods of protection against liability due to the occurrence of unfavorable circumstances of the contract.

Besides, the formal-legal method was used to highlight the features of the concept of force majeure, as well as for the constituents of alternative remedies.

Additionally, the hermeneutic method is reflected in the treatment of the concept of doctrines of foreign law such as hardship, the frustration of purpose, impracticability of contract, material adverse change, etc.

Also, the method of analysis is reflected in the characterization of concepts and facts related to the impact and changes in the contract law of different countries under Covid-19 through their analysis of the main features, principles, concepts, main structural elements, etc.

Finally, the method of synthesis was used to characterize the results obtained in their entirety, to formulate conclusions. 


\section{ANALYSIS OF RECENT RESEARCH}

Most of the publications related to the research topic date back to 2020. Earlier developments mainly involve the analysis of theoretical and legal aspects of metamorphoses of contract law. Analytical materials in this aspect are constantly updated. The advantage in this belongs to journalistic texts, as scientific research requires a wider resource base and time for thorough and objective research. It is also worth mentioning a large number of analytical essays from practicing lawyers, which are like a review of current changes in contract law under the influence of the spread of the Covid-19 pandemic.

Among the names of foreign and domestic experts who have made efforts to cover the research, it is worth mentioning the works of Bradley (2020), Ferguson (2020), Hansen (2020), Renjith (2020), Schwartz (2010, 2020), Twigg-Flesner (2020), Adakhovska (2020), Zakirova (2020), Fronchko, and Tsyomyk (2020).

Thus, Bradley (2020) considered the issue of breach of contract in terms of common law doctrine, drew attention to the peculiarities of protection in the English and American judicial systems. In particular, it analyzed how they adapted to the effects of the coronavirus epidemic and what lawyers, practitioners, entrepreneurs, and legislators should pay attention to when deciding on contracts in times of coronavirus crisis.

Moreover, Ferguson (2020) in his article thoroughly approached the issue of dispute resolution. He reviewed typical examples and the legislation behind them in the field of contracts and drew attention to promising tools, strategies, and tactics for protection against liability for breach of contract affected by the coronavirus crisis.

Besides, Hansen (2020) in his article explored the basic concepts of contract law, which are used to protect against liability for non-performance of the contract due to circumstances beyond the control of the executor (the debtor). The author pays special attention to contracts in the field of construction: contract, capital construction, concession, etc.

Further, Renjith (2020) drew attention to the theoretical and legal aspect of force majeure in the context of the Covid-19 pandemic and possible scenarios for its application. Particular attention is paid to the impact of the spread of the virus on changes in contract law.

Twigg-Flesner (2020) approached the subject of research from a sociological and general theoretical point of view, namely, pointed out the threats posed by Covid-19 to the essence of contract law, how the coronavirus will affect future agreements and the legal consciousness of people. 
Schwartz $(2010,2020)$ in his works explores the loss of the purpose of the contract, the doctrine of a significant change in the terms of the contract. In his work from 2020, he analyzes in detail the examples of various contracts how Covid-19 affects their implementation, as well as how different methods of protection can help to reach agreements under the influence of unforeseen circumstances (force majeure, disadvantage, or inability to perform the contract in the future, etc.) or release of the partyexecutor of the obligation from liability.

In her report, Adakhovska (2020) analyzed possible challenges for Ukraine's contract law related to the impact of coronavirus spread. In particular, it questioned the universal application of force majeure in connection with the imposition of restrictive measures and pointed to the mandatory conditions to be met by a party claiming release based on force majeure.

Zakirova (2020) prepared an analytical report on the opinions of practicing lawyers on how to get Ukrainian business out of the coronary crisis in terms of contract implementation. The author analyzed the pros and cons of the application of the doctrine of force majeure, as well as the feasibility of alternative protection algorithms.

Finally, Fronchko and Tsyomyk (2020) described the structural changes in the contract law of Ukraine that occurred in the early stages of the spread of coronavirus. For example, attention is paid to how the laws adopted by the Verkhovna Rada on the provision of economic and social assistance have affected the sphere of contract law in general and some types of contracts in particular.

\section{RESULTS AND DISCUSSION}

\section{IV.1. Theoretical and Legal Aspects of the Specifics of Changes in Contract Law in a Corona Crisis}

The article considers the main legal mechanisms that apply to contracts in times of crisis. These include force majeure, termination of the obligation due to the impossibility of its implementation, amendments to the contract, termination of the contract due to a significant change in circumstances.

A force majeure is a legal fact, i.e., an event, cause, factor, or circumstance that is a legal basis for release from liability for nonperformance of an obligation if its performance is impossible. A warning of force majeure with a general reference to such circumstances or with an exhaustive list thereof may be contained in the contract or expressly 
provided for in the legal act. However, not all countries have such legislation, so the preference in funds is usually given to contracts. For example, this situation has developed in English law (Sidley, 2020). According to the doctrine of English law, a party is not released from the obligation only because it has become more expensive, more difficult to implement, etc. (Raynes, 2020).

In contrast, following the norms of Ukrainian laws, for example, Art. 617 Civil Code of Ukraine and Art. 218 of the Commercial Code of Ukraine, for compliance with the legal conditions of force majeure, a person can refer to as a reason for non-compliance with the terms of the contract, if there is no provision. In general, the list of conditions for the recognition of circumstances as force majeure is contained in the Law of Ukraine "On Chambers of Commerce and Industry (CCI) in Ukraine". The use of force majeure is of an applicability nature, so it cannot be said that, as a legal category, it exists in the form of abstraction. It should be borne in mind that, one way or another, the issue of force majeure will make sense only if it is applied in a particular case, so even the announcement of the CCI or the indication in the law of the Covid-19 pandemic force majeure does not automatically release the parties from their obligations. Exemption from liability, under contract or law based on force majeure, implies nonapplication non-application, or excuse from the sanctions of the counterparty, for which compliance with the terms of the contract, has become impossible, for the period of force majeure. Therefore, when the possibility of fulfilling the terms of the contract is restored, it can be prosecuted again in the form of damages or penalties, as the circumstances that made it impossible to fulfill the obligation have disappeared, so the counterparty is obliged to comply with the agreement. There is an algorithm of actions necessary for effective registration of force majeure. These include fixing the fact of inability to fulfill the obligation (documentary evidence, evidence), notification of the counterparty, obtaining a certificate of force majeure in the CCI. If a Ukrainian company supplying certain medicines to a foreign counterparty is unable to do so due to a government ban on the export of a specific product (such as drugs or medical masks) to be supplied to a foreign firm under a contract and there is no alternative to do so, then the supplier has the right to apply the above algorithm to absolve itself of liability for non-compliance with the terms of the contract for the period of the government's ban as a force majeure. Other legal mechanisms should be considered in the event of a future default or significant economic difficulties that may be caused by the commitment.

If the obligation is non-monetary, impossible to perform through no fault of any of the counterparties, and one of them, who is unable to perform 
it due to impossibility, has duly notified the other party, then such obligation can be terminated according to Art. 607 of the Civil Code of Ukraine and Art. 205 Commercial Code of Ukraine. In English law, a similar mechanism is called frustration (of purpose) (Sidley, 2020), according to which the obligation is terminated based on loss of original meaning to fulfill it. For example, where a government order requires a farmer to destroy a population of animals that he was required to transfer to a contractor under contract because of coronavirus infection, then he has the right to demand termination of the contract for reasons beyond his control. In such circumstances, if a deposit has been received for a consignment of animals, the party for whom the obligation cannot be fulfilled must return the funds received to the counterparty.

If the parties at the time of concluding the contract were aware of the circumstances under which the conditions would be different, or the contract would not be concluded at all, the contractors may request changes to the contract or its termination. At the same time, the possibility of fulfilling the contract remains, but compliance with the conditions becomes significantly unfavorable for one of the parties. Under the influence of the spread of coronavirus and the introduction of quarantine restrictions, some contracts have become economically unprofitable to perform. In a democratic way, the contractors have the opportunity to agree on minor changes to the contract, which would help minimize the negative consequences. Art. 652 of the Civil Code of Ukraine allows contractors to terminate the contract in court if no agreement can be reached. Some factors should be followed for such protection to work: (i) the parties initially (at the time of the contract) imply that such a change of circumstances will not occur; (ii) with all possible measures taken to eliminate the causes, independent of the party, which contributed to the emergence of negative circumstances, they could not be eliminated; (iii) the initial expectations of the property of the party are not justified in the case of fulfillment of the terms of the contract; and (iv) there is nothing to indicate that the risks of a change in circumstances are assigned to the interested party, in particular, the customs of business or the essence of the contract do not indicate this.

The court may change the terms of the contract in cases where the termination would be contrary to the public interest, but in general, subject to these four conditions, the contract may be terminated in court.

It is also necessary to mention such a concept in contract law as difficulties, or difficult implementation (hardship). According to this idea, the obligation can be changed or terminated. However, in some countries, such as Belgium and England, hardship is a common business risk that does not affect liabilities (Kurilo, 2019). 
Essentially, hardship is a special category of incidents, in the occurrence of which proper performance is still possible, but due to their unpredictability, it becomes significantly complicated. The difference between hardship and force majeure is also the consequences. The party referring to such a change of circumstances may require a modification in the articles of the agreement for its enforcement on satisfactory terms.

Art. 652 of the Civil Code of Ukraine contains 4 conditions under which a party may change or terminate the contract due to a significant change of circumstances (hardship). In addition, here the mention of the Resolution of the Supreme Court of Ukraine on February 20, 2012, is needed. It follows: "The onset of the global financial crisis is not a significant change in the circumstances that guided the parties to the agreement, as the economic crisis is general, and affects both parties, so it cannot be the ground for changing or terminating the contract in court ${ }^{1}$."

In the sense of Art. 79 of the Vienna Convention of 1980, a significant change of circumstances is a special category of "obstacles".

Speaking of improvements that can be made to the legislation of Ukraine regarding the hardship, one of the varieties of the implementation of this doctrine could be changes regarding the suspension of the agreement (in connection with the hardship). The introduction at the legislative level of such a legal structure as "suspension of the contract" would allow the parties to introduce a legal mechanism for settling relations aimed at effectively resolving the problem of temporary suspension of the contract if there are appropriate legal grounds and, as a result, minimize risks of potential recognition, feigned or fictitious (Ivanova, 2016).

According to Art. 79 of the UN Convention on the International Sale of Goods of 1980, the company is not liable for failure to fulfill any of its obligations if it proves that it was caused by an obstacle beyond its control.

\section{IV.2. World Experience}

\section{a) England}

A specific of the English tradition is the lack of particular statutory law on force majeure (Broom \& Brennan, 2020). Moreover, the force majeure provision is something that the parties agree upon, and as a result, they state it explicitly in their contract (Moore, 2020). Additionally, the wording of the contract is essential to denote typical cases of force majeure, if any changes occur, which are in reasonable interrogation with the

\footnotetext{
${ }^{1}$ Resolution of the Supreme Court № 6-93цс11. 20.02.2012. In https://verdictum.ligazakon.net/document/23069464
} 
performance of the contract. It is significant for the interpretation of the contract. However, the parties have the right to state the exact opposite. For example, to refer to the impossibility of performance of the contract under no circumstances. That is, a warning about force majeure may not be included in the contract (Katsivela, 2007; Forbes, 2020).

Hence, the English legal doctrine is characterized by strict compliance with the terms of the contract (ibid.). It is based on the principle that treaties are essentially enforceable (nota bene, the principle of international law pacta sunt servanda) (ibid.). Practically, it means that in the case of a trial, the courts will interpret the provisions of the law and the contract in such a way that recognizing the party as exempt from the obligation will be the last option (Baker Botts, 2020; Diggle, 2020; Diggle \& Welham, 2020; Norton Rose Fulbright, 2020).

Therefore, English courts prefer the position that the exemption of a party from the performance of the contract will negatively affect the essence of the contract law, which implies the parties must comply with the terms of the contract (Gard, 2020). Exceptions are situations where the performance of the contract would be illegal or impossible under any circumstances (Katsivela, 2007). It is worth emphasizing that this is the categorical position of the whole English approach: if a party can fulfill its obligations, it must fulfill them, because it is the essence of the obligation.

The frustration of purpose in English law is used when the fulfillment of the obligation does not make sense. For example, in Krell v. Henry (1903) the court concluded that the lease of the premises lost the purpose of its performance. That fact occurred because the tenant could not see the process of the coronation of the king, for which he rented the apartments. Eventually, the king fell ill before the coronation, and did not come to the event on a certain date. Therefore, the obligations of the parties ceased.

An example of legal logic in a situation of the impossibility of performance of the contract can be the judgments of the court in the case of Taylor v. Caldwell (1863) when the court concluded that the fact of destruction of the house due to its sudden fire made it impossible to sell, and therefore the parties are released from liability. Before this historic decision, there were no such precedents for discharge - the parties were closely bound by the terms of the contract.

Aforementioned examples show that the recognition of parties' right to be released from the obligation is not a simple requirement, but must meet certain criteria (Sidley, 2020). Such in English law is justice and reasonableness. Thus, English courts, when applying the doctrine of frustration of purpose/impossibility, must make a decision that will be just and reasonable concerning the new circumstances of the situation 
(Katsivela, 2007). In turn, making such a decision requires what is considered common sense. Therefore, it can be stated that in releasing a party from the obligation due to the loss of the meaning of its performance/impossibility of performance, the English courts are guided by the principles of fairness and reasonableness, which are based on a more general design of common sense (ibid.). However, it should be noted that this is only possible if the circumstances of the new situation go beyond what is normally taken into account (normally considered risks) (Blum, 2007).

\section{b) The United States}

In the context of the impact of coronavirus on contractual relations in the United States, it would be appropriate to distinguish the legislation of one state, to which all others will be similar. In general, New York law generally meets this criterion, as commercial parties most often choose to regulate the state for trading (Linklaters, 2020b).

Under New York state law (The New York State Senate Website, 2021), the parties to the contract are guaranteed the choice of state law to regulate contract matters. According to Art. 5-1401 (1) New York's General Obligations Law (i.e., New York's Statutory Law on Contracts), parties to a contract of at least 250,000 dollars have the right to choose New York State law as primary (Linklaters, 2020b). It is also noted that the laws of the state of Delaware are popular among traders to regulate relations between them. Under New York law, courts have the right to recognize the validity of another law for commercial contracts if it is inextricably linked to the substance of the contract and does not conflict with the fundamentals of New York public policy. However, New York's statutory contract law does not contain any provisions relating to force majeure. Usually, the courts of New York interpret the warning about force majeure in the contract in a very narrow sense, without giving it expansive meaning, pushing the parties as much as possible to implement the agreements.

As noted in their review article on the impact of quarantine on contract law in the United States, Peacock \& Henriques (2020), coronavirus control measures have heterogeneous legal bases in each state or even city in one state. For example, whether an enterprise has to reduce its activity or close down for a lockdown period plays a key role in deciding whether it is a critical or nonessential business. The state of California used the Memorandum on Identification of Essential Critical Infrastructure Workers during Covid-19 Response, issued by the US Department of Homeland Security, Cybersecurity \& Infrastructure Security Agency (CISA) (2021), to identify such facilities. This document is recommendatory and identifies 16 
critical infrastructure sectors following the National Infrastructure Protection Plan (NIPP). At the same time, there is uncertainty about what to consider a significant or insignificant business in a pandemic (Alameda County Public Health Department, 2021). For example, in San Francisco (Alameda County, California), there are different rules from the state, and the states of New York (The Official Website of the State of New York, 2020) and Pennsylvania have different approaches to the definition of critical infrastructure (Commonwealth of Pennsylvania, 2020).

As a general rule, the party that has not fulfilled the terms of the contract is liable, unless it justifies the circumstances to which it refers as a basis for exemption from its terms. Such judgments are contained in the case of Cater v. Barker (2005), heard by the North Carolina Court of Appeals. $\mathrm{He}$, in turn, in making the decision, took into account the motivating part of the decision in the case of Blount-Midyette v. Aeroglide Corp. (1961).

In American law, the specifics of contractual disputes over noncompliance with the terms of the contract under the influence of lockdown and the Covid-19 pandemic can be divided into the following categories: (i) the impossibility/impracticality of the contract; (ii) frustration of purpose; and (iii) force majeure.

According to the principles of the first category, the party should not be liable under a contract that it could not perform. For example, a contract for a theatrical show is impossible to perform if the theater where it is to take place is closed by municipal or federal authorities under quarantine restrictions, and there is no other option. Some courts also allow protection against contractual obligations for inexpediency. On the example of a theatrical performance, a party seeking to be exempted from the terms of the contract must prove that the performance is aggravated by an emergency. Following the general rules, for this purpose the event should be: (i) unpredictable (but not incomprehensible); (ii) does not occur through the fault of the party seeking release from the obligation; and (iii) must not meet the basic assumptions of the parties at the time of the contract.

Violation of the purpose of the contract (it is also possible to mean distress/distortion/disorder/deterioration of the purpose or loss of benefit or loss of meaning) is similar to impracticality/inexpediency of performance of the contract. According to the concept of goal frustration, a party can be released from the obligation if the emergency fundamentally changes the nature of the contract and makes the fulfillment of its terms by one party is of no use to the other. This concept is different from the inability to perform one's duties under a contract. Returning to the example of the play, if the contract provided for the cleaning of the theater after it, then its cancellation would distort the purpose of the contract. In this case, the contract can still 
be fulfilled, as both the cleaning staff and the theater are available, but the purpose (cleaning up after the performance) has been ruined, making cleaning a futile effort.

The peculiarity of exemption from liability due to force majeure in American law is that a reservation to this effect should usually be specified in the contract. Thus, force majeure in the form of a coronavirus pandemic can take two forms: if it is covered by a more general clause in the contract or directly provided for in the list of examples of force majeure. For example, the first form often includes circumstances such as "Act of God", extreme weather events, riots, wars or invasions, restrictive government measures, strikes, terrorism or embargoes, etc. Provisions on force majeure, which explicitly provide for a global emergency, pandemic, or epidemic as force majeure circumstances, are less common, but for obvious reasons, these circumstances will be included in the list of force majeure in the new treaties. In addition to force majeure, many courts also require a party to demonstrate an attempt to perform a contract despite an unforeseen event (in our case, the Covid-19 pandemic), possibly by finding an alternative source of supply, such as in Gulf Oil Corp. v. F.E.R.C. (1983), heard by the U.S. District Court of Appeal.

In some states, there are specific rules for reporting force majeure, so you should pay attention to practical issues related to the contract process. Given this, companies must consult with lawyers as to when and in what form they should warn their counterparties about the application of the condition of exemption from the contract due to force majeure. If the company refers to excessive costs incurred, losses due to quarantine restrictions, the Covid-19 pandemic, it is necessary to keep all documentation on the circumstances and losses, as well as documents confirming the causal link between the pandemic and the costs incurred, the impossibility of fulfilling the contract, etc. One way or another, the best strategy for companies should first be to find a compromise on whether to postpone the contract, until a certain point in the future, when favorable circumstances arise.

\section{c) Thailand (Kingdom of Thailand)}

Common features with the measures taken to prevent and respond to coronavirus in terms of ensuring the stability of contractual relations can be traced in the legislation of Thailand. There, on May 24, 2020, the Committee on Public Procurement and Supply Management approved regulations on contracts between individuals during the Covid-19 pandemic, thus recognizing it as force majeure, and ordered force majeure to be calculated 
from the date of the state of emergency. March 26, 2020 (R\&T Thailand, 2020). Thus, there are two approaches to force majeure agreements under Thai law. The first is that contracts without force majeure are automatically subject to force majeure provisions under Section 8 of the Civil and Commercial Code of Thailand (Chandler MHM, 2020). In the second case, the parties agree and specify in the contract the algorithm of action in case of force majeure. These conditions may relate to release from liability, the right to terminate or revise the contract, as well as the distribution of damages due to force majeure. It should be borne in mind that interpreting the provisions of the treaty will play a role, whether there were explicit examples of force majeure such as epidemics, pandemics, quarantine, specific natural disasters such as hurricanes on a scale with appropriate scores, tsunamis, typhoons, floods, earthquakes, etc. Thus, the direct prediction of a pandemic as an example of force majeure in a contract facilitates the release of a party from liability for non-performance of obligations under the terms of the contract or inability to perform them in full (Mazars, 2020). At the same time, the absence of specific examples imposes on the party seeking exemption from force majeure the obligation to prove a causal link between the factors referred to by that party as force majeure and the inability to fulfill the terms of the contract (Mendiola, 2020; Sornchangwat, Thammateeradaycho, \& Ramirez, 2020). In this context, reference may be made to the judgment of the Supreme Court of the Kingdom of Thailand $n^{\circ} 5353 / 2552$ concerning the H5N1 bird flu event (Eder, 2020). According to the plot, the farmer had to slaughter his chickens after an order from the authorities due to the infection of animals with a new flu virus. As a result, the farmer was unable to fulfill his obligation to the customer under the supply contract. The court ruled that the farmer had no obligation to provide the client with chickens, as this had become impossible due to force majeure. However, the peculiarity of this case was the detailed consideration by the court of each aspect of the contract with sectoral division and the application of the analysis of circumstances to determine the place of force majeure under each of the terms of the contract. Therefore, this judicial institution will take this precedent into account only in terms of the trial algorithm, but not for resolving similar cases that will reach the Supreme Court after the Covid-19 pandemic, in essence.

\section{d) Laws of the Middle East}

Art. 273 of the United Arab Emirates Federal Law n ${ }^{\circ} 5$ of 1985 (Civil Code) regulates the issue of force majeure, according to which it arises in bilateral relations when it is impossible to fulfill the obligation. Art. 188 of 
the Law of Qatar $n^{\circ} 22$ of 2004 contains a similar provision. Art. 172 of the Decree of the Sultan of Oman $n^{\circ} 29$ of 2013 allows the termination of the contract due to force majeure, the impossibility of fulfilling the obligation under the terms of the contract. In this case, the debtor, for whom compliance with the terms of the contract became impossible due to force majeure, may also refer to Art. 339 of the decree of the Sultan, according to which «the obligation is terminated if the debtor proves that its performance becomes impossible due to an external reason beyond his will». However, it is noted that according to Art. 159 of the decree, the Covid-19 pandemic can be considered an unforeseen circumstance, which poses significant difficulties for the fulfillment of obligations, but does not make their fulfillment impossible (Oman Law Blog, 2014). In this case, any judge or arbitrator will have a wide discrete power to decide the division of obligations under the contract in each case (there will be discretion in each case, on a case-by-case basis). Art. 215 of the Kuwaiti Decree ${ }^{\circ} 67$ of 1980 (Kuwait Civil Code) contains a warning of force majeure. St. 161 of the Libyan Civil Code of 1954 states that the obligation is repaid, and the contract is terminated if its conditions cannot be met (Meredith \& al-Arif, 1954). Saudi Arabia does not have a codified act in the field of civil law, but the parties have the right to declare force majeure following the legal concept of "Gharar" under Sharia law. According to this concept, risky and dangerous actions for the parties can be a condition for release from the obligation (Angle, Sharratt, Hartley, $\&$ Safle, 2020).

These rules, however, do not contain an exhaustive list of circumstances that fall under the concept of force majeure, so each such circumstance will be considered separately. The fact that the parties envisaged an epidemic as an example of force majeure, in particular, the negative impact or consequences of a specific epidemic (pandemic) of Covid-19, will also play a significant role.

\section{e) China (People's Republic of China)}

Clause 180 of the People's Republic of China General Provisions of the Civil Law (民法总则 in Mandarin) and Clauses 94 (1), 117 and 118 of the Contract Law (合同法 in Mandarin) contain legislative provisions relating to force majeure (Linklaters, 2020a; Liu \& Bai, 2020). According to these instructions, the injured party may be partially or completely released from his obligations and/or liability.

If one of the parties to the contract is a non-resident, the contractors have the right to choose the regulatory legislation. This requires that one or 
more of the following conditions be met: (i) any party is a foreign natural or legal person (the mere existence of property abroad is not sufficient to choose other legislation); (ii) the subject of the agreement was outside mainland China; and (iii) legal facts that give rise to, change or terminate the contractual relationship took place outside mainland China (Linklaters, 2020a).

In all other cases, national law will be regulatory for resident countries of the People's Republic of China. Chinese national law will also govern agreements on joint ventures for exploitation and development between mainland China and a foreign country, which are implemented within mainland China.

Traditionally, China is not considered a state of developed case law. However, in 2003, the Supreme People's Court (SPCC) published case-law on contracts affected by the spread of Severe Acute Respiratory Syndrome ("SARS") (Linklaters, 2020a). Following the Covid-19 outbreak, local courts have issued guidelines on the impact of the epidemic on contractual obligations, as well as on the applicability of the "significant change" doctrine to agreements affected by the coronavirus outbreak. The doctrine of "material adverse change" is generally very similar to Western options for unforeseen liability, in particular, the frustration of purpose and hardship. Although the injured party cannot unilaterally terminate the contract, it is allowed to ask the court to amend the contract due to a significant change in circumstances, and if it is impossible to achieve the contractual goal- to ask the court to terminate the contract. However, in practice, the courts of the PRC follow a conservative approach, applying this doctrine. Therefore, like the US courts, they try to push the parties to fulfill their obligations, as a result of which the court amends or terminates the contract according to the above doctrine often has to go through the court until approved by the Supreme Court (Liu \& Bai, 2020).

The China Council for the Promotion of International Trade (Deloitte, 2020; Liu \& Bai, 2020) certifies force majeure in China. The first "coronavirus" certificate of force majeure was issued by her on February 2, 2020, to an auto parts manufacturer in Huzhou, Zhejiang Province (Liu \& Bai, 2020). As of February 14, 2020, the Council has already issued more than 1,600 force majeure certificates covering contracts totaling approximately 15.7 billion dollars (Deloitte, 2020).

\section{f) National Legislation of Ukraine}

According to Ukrainian law, the Chamber of Commerce and Industry of Ukraine and its regional branches issue legal certificates of force majeure 
(Legal Hundred, 2020). Following Law $n^{\circ}$ 530-IX of 17.03.2020, the list of force majeure circumstances (which is contained in Part 2 of Art. 14-1 of the Law of Ukraine "On Chambers of Commerce and Industry in Ukraine") was supplemented by "the quarantine" established by the Cabinet of Ministers of Ukraine. It is interesting that a few days before that, the CCI of Ukraine, in its press release, did not recognize quarantine as a force majeure circumstance (Interfax-Ukraine, 2020a).

The procedure for applying for force majeure to the CCI was simplified under the pandemic (Legal Hundred, 2020; Lavrushina, Danileyko, Drug, Yaremko, 2020; Liga: Zakon, 2020). The application can be submitted electronically for each contract, in respect of which force majeure has arisen, confirming the causal link between the lockdown and the inability to fulfill the obligation (Lavrushina et al., 2020). Applicants, who are business entities, are usually issued a document within 7 days. For individuals, the period may be up to 21 days. For small businesses, a certificate of force majeure is issued free of charge.

In itself, the recognition of quarantine as a force majeure does not give precedence in the lawsuit to the party who will refer to it as a reason for exemption from penalties, because it will be necessary to prove a causal link between force majeure and the impossibility of fulfilling the terms of the contract - that it was quarantine that hindered the fulfillment of obligations, that it was impossible to fulfill the obligation in any other way (Kurilo, 2019; Lavrushina et al., 2020; Sussel, 2020; Tytarenko, 2020). The court also takes into account such signs of force majeure as emergency and insubordination, unpredictability, inevitability (Adakhovska, 2020; Lavrushina et al., 2020; Fronchko \& Tsyomyk, 2020).

Attention should be paid to the procedure for informing the counterparty. A large number of practicing lawyers in this aspect advise to start contacting the contractor as soon as possible and agree in a pre-trial procedure (Deloitte, nd; Interfax-Ukraine, 2020b; Legal Hundred, 2020; Adakhovska, 2020; Zakirova, 2020; Kurilo, 2020; Lavrushina et al., 2020; Sussel, 2020; Titarenko, 2020; Fronchko \& Tsyomyk, 2020). The further course of the agreements on release from liability for non-performance of contractual obligations on the basis of force majeure may depend on the observance of the procedure for sending a notice to the other party to the contract. Note that if a party is released from liability under force majeure, it is not released from the obligation. If the main purpose of the contract cannot be achieved due to force majeure, the condition of giving the party the opportunity to unilaterally terminate the contract should be considered (Lavrushina et al., 2020). 
Given the experience in the field of contract law of foreign countries, especially the Anglo-Saxon legal family, we can say that the crisis is a kind of litmus test to test the high contractual discipline and business reputation of market participants. Given the research studied, it becomes clear that a legal tradition of these countries, such as England and the United States, is to strictly follow the terms of the contract, i.e., the principle of good faith performance. Therefore, the so-called "Large-scale concerns about mass non-performance of contracts", which began in the Ukrainian business environment, from this point of view may be criticized for good faith performance-whether the counterparties seek to fulfill the terms of the contract in spite of everything, or take the first opportunity to evade (Deloitte, 2020; Lavrushina et al., 2020; Liga: Zakon, 2020). Therefore, in this aspect, raising the issue of force majeure is in some ways an incompatible and excessive strategy, which should not be started without using "softer" corrective means in the early stages of the crisis. However, it is impossible to rule out a scenario in which it would be more profitable for entities to first apply to force majeure, putting their liability on hold, then to change based on a significant change of circumstances, and then to stop due to the impossibility of implementation (Lavrushina et al., 2020). But it will depend on the specific case, that is, on what strategy the entity chooses to depend on the difficulty of using alternatives.

Following the amendments made by Law $\mathrm{n}^{\circ}$ 540-IX of March 30, 2020, to the Civil Code of Ukraine (paragraph 13 of the Final and Transitional Provisions was added), it is prohibited to increase interest rates on loan agreements for the period of quarantine. On December 9, 2020, the Cabinet of Ministers adopted Resolution $\mathrm{n}^{\circ} 1236$, according to which the quarantine was extended until February 28, 2021.

As the case-law on the effects of coronavirus on contracts is just beginning to take shape, it is worth mentioning the litigation, which can serve as a model for resolving such disputes over non-compliance with the terms of the contract due to quarantine restrictions. This is the decision of the Kyiv Commercial Court of Appeal of 16.03.2011 $\mathrm{n}^{\circ}$ 18/90-39/268, according to which the defendant referred to the Resolution of the Cabinet of Ministers of Ukraine of 30 October $2009 \mathrm{n}^{\circ} 1152$ "On prevention of the spread of influenza type A/H1N1/California/04/09 and acute respiratory diseases among the population" as a reason that made it impossible to comply with the terms of the contract (conducting a stipulated promotional event). Then, under the contract between the parties, an agreement was reached on advertising actions by the defendant, for which the plaintiff undertook to provide the defendant with funds in the amount of 200,000 Ukrainian hryvnia (half of which as a subscription). The received 
subscription was not returned to the plaintiff, and the event itself was taken 3.5 months later when the plaintiff had already lost interest in holding it. At the same time, after the introduction of quarantine restrictions, the defendant refused to return the funds, outside the contract unilaterally decided to hold an advertising event outside the stipulated period, without returning the funds despite the notice of the plaintiff. The court did not take into account the arguments of the defendant that the reason for non-compliance with the terms of the contract were quarantine restrictions, since the property dispute concerned the return of subscription under the terms of the contract, according to which the plaintiff had the right to terminate it unilaterally. The defendant had to return the funds provided if the work was not performed or the services were not provided within the period specified in the contract. Thus, the defendant's reference to the Resolution of the Cabinet of Ministers as a force majeure was considered inappropriate by the court, as it would concern the imposition of penalties as liability for non-performance or improper performance of the contract, and this property dispute concerned the return of subscription under the contract. Given the above, the appellate court rejected the arguments of the defendant's complaint and upheld the decision of the court of the first instance.

\section{CONCLUSIONS}

1. In terms of understanding the meaning of the concept of force majeure, all countries which accept this doctrine come to a consensus that such circumstances should be unpredictable, irreversible, and independent of the will of the parties. Additionally, a common feature is the certification of force majeure by the relevant institutions of commerce, which are often called Chambers of Commerce and Industry.

2. The difference between the legal systems of the continental and Anglo-Saxon legal family lies in their approach to the circumstances of exemption from liability. The latter is characterized by strict adherence to the principle of good faith and equity. As a result, common-law courts try to encourage the parties to fulfill their obligations as much as possible. For the same reason, the statutory law of countries such as England and the United States does not regulate force majeure but favors the interpretation of the contract in court. Considering force majeure the least desirable remedy, common law courts may allow the injured party to use the doctrines of the frustration of purpose or hardship, which are of similar use in continental law countries. 


\section{REFERENCES}

Adakhovska, N. (2020). On the issue of granting the COVID-19 pandemic the status of force majeure. Problems of legal regulation of civil relations in the conditions of COVID-19, 1, 30-32. In http://dspace.onua.edu.ua/handle/11300/12616.

Alameda County Public Health Department. (2021). In https://acphd.org/media/559658/health-officer-order-shelter-in-place20200316.pdf.

Alon, T., Doepke, M., Olmstead-Rumsey, J., \& Tertilt, M. (2020). The impact of COVID19 on gender equality (No. w26947). National Bureau of Economic Research. Working Paper Series. In https://www.genderportal.eu/sites/default/files/resource_pool/w26947.pdf.

Anand, K., Karade, S., Sen, S., \& Gupta, R. (2020). SARS-CoV-2: Camazotz's Curse. Medical Journal, Armed Forces India, 76(2), 136-141. In https://www.ncbi.nlm.nih.gov/pmc/articles/PMC7183968/.

Andersen, K., Rambaut, A., Lipkin, W., Holmes, E., \& Garry, R. (2020). The proximal origin of SARS-CoV-2. Nature Medicine, 26(4), 450-452. doi: 10.1038/s41591020-0820-9.

Angle, S., Sharratt, N., Hartley, M., \& Safle, T. (March 23, 2020). COVID-19: Legal and contractual implications. In https://www.shlegal.com/news/covid-19-legal-andcontractual-implications.

Baker Botts. (April 29, 2020). Application of Force Majeure under English Law, New York Law and Russian Law (Comparative Analysis). In https://www.bakerbotts.com/ /media/files/insights/publications/2020/april/appl ication-of-force-majeure-under-english-law-new-york-law-and-russianlaw.pdf?la=en\&hash=3415296E35AB2D585BFD0F14F7EE2B0D7355752A.

Bartik, A., Bertrand, M., Cullen, Z., Glaeser, E., Luca, M., \& Stanton, C. (2020). The impact of COVID-19 on small business outcomes and expectations. Proceedings of the National Academy of Sciences, 117(30), 17656-17666. doi: 10.1073/pnas.2006991117.

Blum, B. (2007). Contracts: examples \& explanations. Aspen Publishers Online.

Bradley, A. (May 11, 2020). Coronavirus: Can I get out of this contract? Breach of Contract, Force Majeure or Frustration. Keystone Law. In https://www.keystonelaw.com/keynotes/coronavirus-can-i-get-out-of-thiscontract-breach-of-contract-force-majeure-or-frustration.

Broom, R., \& Brennan, P. (April 29, 2020). Invoking Force Majeure Due to COVID-19 Under English Law. In https://www.squirepattonboggs.com//media/files/insights/publications/2020/04/invoking-force-majeure-due-tocovid-19-under-english-law/invoking-force-majeure-due-to-covid-19-underenglish-law.pdf.

Chandler MHM (March 26, 2020). COVID 19. Understanding the applicability of force majeure in Thailand. In 
https://www.chandlermhm.com/content/files/00000407/CMHM\%20Newsletter $\% 20$ Force\%20Majeure.pdf.

Clyde\&Co. (April 1, 2020). COVID-19 UK: Force majeure... or simple frustration?

Knowing where you stand in uncertain times. In https://www.clydeco.com/en/insights/2020/04/farce-majeure-or-simplefrustration-knowing-where.

Commonwealth of Pennsylvania. (2020). Order of the Governor of the regarding the closure of all businesses that are not life sustaining. In https://www.governor.pa.gov/wp-content/uploads/2020/03/20200319-TWWCOVID-19-business-closure-order.pdf.

Cybersecurity \& Infrastructure Security Agency. (2021). Guidance on the essential critical infrastructure workforce. In https://www.cisa.gov/publication/guidanceessential-critical-infrastructure-workforce.

Deloitte. (2020). “Antiviral” measures for business: recommendations of lawyers (Part 1). In https://www2.deloitte.com/ua/uk/pages/press-room/deloittepress/2020/covid19-measures-for-business-1.html.

Diggle, N. (April 7, 2020). English contract law. A force majeure guide. https://www.blakemorgan.co.uk/english-contract-law-a-force-majeure-guide/.

Diggle, N., \& Welham, H. (April 7, 2020). Guide to force majeure and other Covid-19 contract issues. In https://www.blakemorgan.co.uk/wpcontent/uploads/Downloads/Guides/Blake-Morgan-COVID-19-Force-Majeureand-other-Contract-Issues-Guide-updated.pdf.

Dovgert, A. (2019). Recodification of the Civil Code of Ukraine: the main factors and prerequisites for the start. Law of Ukraine, 1, 27-41.

Eder, U. (March 9, 2020). Force Majeure in Thailand: From the Bird Flu Case to the Coronavirus Outbreak. In https://www.linkedin.com/pulse/force-majeurethailand-from-bird-flu-case-coronavirus-dr-ulrich-eder/.

Ferguson, J. (2020), Arbitrating Covid-19 Contract Disputes Under Civil and Common Law Principles. Alternatives to the High Cost of Litigation, 38, 134-145. doi: 10.1002/alt.21857.

Forbes, Z. (n.d.). COVID-19: Force majeure \& frustration under English law. In https://bioone.org/documents/Publisher\%20Resources/COVID19\%20Resources/Force\%20Majeure\%20and\%20Frustration-ALPSP1Jun20.pdf.

Fronchko, V., \& Tsyomyk, V. (2020). The coronavirus pandemic (COVID-19) as a force majeure factor in the fulfillment of contractual obligations. Current issues of jurisprudence, 2(22), 125-130. doi: 10.35774/app2020.02.125.

Gard (April 1, 2020). COVID-19 and force majeure clauses under English law. In https://www.gard.no/web/updates/content/29452615/covid-19-and-forcemajeure-clauses-under-english-law. 
Gostin, L., \& Hodge, J. (2020). US emergency legal responses to novel coronavirus: balancing public health and civil liberties. JAMA, 323(12), 1131-1132. In https://jamanetwork.com/journals/jama/fullarticle/2761556.

Gostin, L., \& Wiley, L. (2020). Governmental Public Health Powers During the COVID19 Pandemic: Stay-at-home Orders, Business Closures, and Travel Restrictions. JAMA, 323(21), 2137-2138. doi:10.1001/jama.2020.5460. In https://digitalcommons.wcl.american.edu/facsch_lawrev/1860?utm_source=digi talcommons.wcl.american.edu\%2Ffacsch_lawrev\%2F1860\&utm_medium=PD F\&utm_campaign=PDFCoverPages.

Grover, S., Sahool, S., Mehra, A., Avasthi, A., Tripathi, A., Subramanyan, A., Pattojoshi, A., Rao, GP., Saha, G., Mishra, K.K., Chakraborty, K., Rao, N.P., Vaishnav, M., Singh, O.P., Dalal, P.K., Chadda, R.K., Gupta, R., Gautam, S., Sarkar, S., Rao, T.S.S., Kumar, V., \& Reddy, Y.C.J. (2020). Psychological impact of COVID-19 lockdown: An online survey from India. Indian Journal of Psychiatry, 62(4), 354-362. doi: 10.4103/psychiatry.IndianJPsychiatry_427_20.

Hansen, S. (2020). Does the COVID-19 Outbreak Constitute a Force Majeure Event? A Pandemic Impact on Construction Contracts. Journal of the Civil Engineering Forum, 6, 201-214. doi:10.22146/jcef.54997.

Interfax-Ukraine (March 12, 2020a). Quarantine is not force majeure. CCI. In https://ua.interfax.com.ua/news/economic/646511.html.

Interfax-Ukraine (March 5, 2020b). Businesses will have to prove the impact of the coronavirus on the non-performance of contracts for the recognition of force majeure-lawyers. In https://ua.interfax.com.ua/news/economic/645136.html.

Ivanova, O. (July, 2016). On the issue of introducing a new legal structure of "the suspension of the contract". Liga: Zakon. In https://uz.ligazakon.ua/ua/magazine_article/EA009368.

Katsivela, M. (2007). Contracts: Force Majeure Concept or Force Majeure Clauses. Unif. L. Rev. ns, 12, 101. In https://heinonline.org/HOL/LandingPage?handle=hein.journals/droit2007\&div $=7 \&$ id $=$ \&page.

Kharytonov, E. (2020). Legal regulation of civil relations in a pandemic: between private and public law. Legal life of modern Ukraine, 3, 388-391. In https://hdl.handle.net/11300/13362.

Kharytonov, E., \& Kharytonova, O. (2020a). Political values and recodification of Ukrainian civil law. Journal of Civil law, 36, 18-24. doi: 10.32837/chc.v0i36.195.

Kharytonov, E., \& Kharytonova, O. (2020b). Civilization before the challenges of the pandemic. Journal of Civil law, 37, 5-9. doi: 10.32837/chc.v0i37.341.

Kingdom of Thailand. Supreme Court. (2012). Decision 5353/2552. In https://deka.in.th/view-508258.html.

England. Krell v. Henry (1903). In https://www.lawteacher.net/cases/krell-v-henry.php. 
Kurilo, Y. (January 29, 2019). The theory of force majeure: how to prove the circumstances of force majeure in different countries. Mind. In https://mind.ua/openmind/20193086-teoriya-fors-mazhoriv-yak-dovestiobstavini-neperebornoyi-sili-u-riznih-krayinah.

Kurilo, Y. (March 11, 2020). Is Coronavirus Force Majeure? Novoe Vremia. In https://nv.ua/ukr/biz/experts/koronavirus-i-karantin-chi-fors-mazhor-ce-i-yakbudut-virishuvatisya-spirni-momenti-v-biznesi-poradi-yurista-50074978.html.

Kuwait. (1980). Civil Code: Decree-law n 67. In https://www.icnl.org/wpcontent/uploads/Kuwait_KuwaitCivilCode1980.pdf.

Lavrushina, V., Danileyko, A., Drug, O., \& Yaremko, V. (April 6, 2020). Legal consequences of the spread of coronavirus COVID-19 for the execution of contracts. In https://sk.ua/uk/news-uk/pravovi-naslidki-poshirennya-koronavi/.

Legal Hundred. (September 13, 2020). Quarantine as a force majeure. In https://legal100.org.ua/karantin-yak-fors-mazhor/.

Liga: Zakon. (December 22, 2020). Can lockdown be considered force majeure? In https://biz.ligazakon.net/analitycs/200495_chi-mozhna-vvazhati-lokdaun-forsmazhorom.

Linklaters. (March 12, 2020a). Covid-19: Impact on commercial contracts. Mainland China. In https://www.linklaters.com/en/insights/publications/2020/march/novelcoronavirus-commercial-contracts/novel-coronavirus-impact-on-commercialcontracts/mainland-china.

Linklaters. (March 12, 2020b). Covid-19: Impact on commercial contracts. The US. In https://www.linklaters.com/en/insights/publications/2020/march/novelcoronavirus-commercial-contracts/novel-coronavirus-impact-on-commercialcontracts/us.

Liu, J., \& Bai, C. (March 16, 2020). Coronavirus in the Chinese Law Context: Force Majeure and Material Adverse Change. Pillsbury. In https://www.pillsburylaw.com/en/news-and-insights/coronavirus-in-thechinese-law-context-force-majeure-and-material-adverse-change.html.

Lu, H., Stratton, C., \& Tang, Y. (2020). Outbreak of pneumonia of unknown etiology in Wuhan, China: The mystery and the miracle. Journal of Medical Virology, 92(4), 401-402. In https://onlinelibrary.wiley.com/doi/pdf/10.1002/jmv.25678.

Lu, R., Zhao, X., Li, J., Niu, P., Yang, B., Wu, H., Wang, W., Song, H., Huang, B., Zhu, N., Bi, Y., Ma, X., Zhan, F., Wang, L., Hu, T., Zhou, H., Hu, Z., Zhou, W., Zhao, L., Chen, J., Meng, Y., Wang, J., Lin, Y., Yuan, J., Xie, Z., Ma, J., Liu, W.J., Wang, D., Xu, W., Holmes, E.C., Gao, G.F., Wu, G., Chen, W., Shi, W., \& Tan, W. (2020). Genomic characterisation and epidemiology of 2019 novel coronavirus: implications for virus origins and receptor binding. Lancet, 395(10224), 565-574. doi: 10.1016/S0140-6736(20)30251-8.

Mazars. (April 22, 2020). Force Majeure and COVID-19. In https://www.mazars.co.th/Home/Insights/COVID-19-impact/Force-Majeureand-COVID-19. 
McKibbin, W., \& Fernando, R. (2020). The economic impact of COVID-19. Economics in the Time of COVID-19, 45, 1-14. In https://www.incae.edu/sites/default/files/covid-19.pdf\#page=52.

Mendiola, J. (August 20, 2020). Thailand: Applying Force Majeure To Contractual Obligations During The COVID-19 Crisis. Silk Legal. In https://www.mondaq.com/litigation-contracts-and-forcemajeure/971502/applying-force-majeure-to-contractual-obligations-during-thecovid-19-crisis?type=related\#_ftn7.

Meredith, O., \& al-Arif, I. (1954). The Libyan Civil Code: an English translation and a comparison with the Egyptian Civil Code. Cambridge, England: Oleander Press. In https://www.ilo.org/dyn/natlex/docs/MONOGRAPH/26463/56730/F202491963 9/LYB26463\%20Eng.pdf.

Moore, F. (March 26, 2020). Will Covid-19 trigger a force majeure clause? In https://www.pinsentmasons.com/out-law/guides/covid-19-force-majeureclause.

Nicola, M., Alsafi, Z., Sohrabi, C., Kerwan, A., Al-Jabir, A., Iosifidis, C., Agha, M., \& Agha, R. (2020). The socio-economic implications of the coronavirus pandemic (COVID-19): A review. International Journal of Surgery, 78, 185-193. doi: 10.1016/j.ijsu.2020.04.018.

Norton Rose Fulbright (March, 2020). Force majeure/hardship clauses and frustration in English law contracts amid COVID-19. In https://www.nortonrosefulbright.com/en/knowledge/publications/b54cf723/forc e-majeure-hardship-clauses-and-frustration-in-english-law-contracts-amidcovid-19.

Oman Law Blog. (November 3, 2014). The Civil Transactions Law and the Impact of the Muqawala Provisions on Construction. In https://omanlawblog.curtis.com/2014/11/the-civil-transactions-law-andimpact.html.

Parmet, W., \& Sinha, M. (2020). Covid-19. The law and limits of quarantine. New England Journal of Medicine, 382(15), e28. doi: 10.1056/NEJMp2004211.

Peacock, D., \& Henriques, M. (April 7, 2020). Push the Pause Button? Contracts and COVID-19. National Law Review, 10(98), 1-10. In https://www.natlawreview.com/article/push-pause-button-contracts-and-covid19.

Qatar. (2004). Regarding Promulgating the Civil Code: Law 22. In https://www.almeezan.qa/LawView.aspx?opt\&LawID=2559\&language=en\#: : text $=$ No $\% 20$ person $\% 20$ who $\% 20$ lacks $\% 20$ discretion,reached $\% 20$ the $\% 20$ age $\% 2$ 0of\%20discretion.

Rajah \&Tann Thailand (April, 2020). COVID-19: Force Majeure in Commercial Transactions in the Current Situation. In https://th.rajahtannasia.com/media/3884/th_2020_04_force_majeure_and_com mercial_transactions.pdf. 
Raynes, J. (April, 2020). COVID-19: English Law Contracts. Force Majeure, Frustration, and Other Relief. Steptoe. In https://www.steptoe.com/en/newspublications/covid-19-english-law-contracts-force-majeure-frustration-andother-relief.html.

Renjith, M. (2020). Force-Majeure under Contract Law in the Context of Covid-19 Pandemic. SSRN. In https://ssrn.com/abstract=3588338.

Schwartz, A. (2010). A 'Standard Clause Analysis' of the Frustration Doctrine and the Material Adverse Change Clause. UCLA Law Review, 57, 1-8. In https://ssrn.com/abstract=1466131.

Schwartz, A. (2020). Contracts and COVID-19. Stanford Law Review, 73, 48-49. In https://www.stanfordlawreview.org/online/contracts-and-covid-19/.

Serafini, G., Parmigiani, B., Amerio, A., Aguglia, A., Sher, L., \& Amore, M. (2020). The psychological impact of COVID-19 on the mental health in the general population. QJM: An International Journal of Medicine, 113(8), 531-537. In https://www.ncbi.nlm.nih.gov/pmc/articles/PMC7337855/.

Sidley. (March 16, 2020). COVID-19 and the Impact on English Law Governed Contracts. Force Majeure and Frustration. In https://www.sidley.com/en/insights/newsupdates/2020/03/covid-19-and-theimpact-on-english-law-governed-contracts--force-majeure-and-frustration.

Sohrabi, C., Alsafi, Z., O’Neill, N., Khan, M., Kerwan, A., Al-Jabir, A., Iosifidis, C., \& Agha, R. (2020). World Health Organization declares global emergency: A review of the 2019 novel coronavirus (COVID-19). International Journal of Surgery, 76, 71-76. doi: 10.1016/j.ijsu.2020.02.034.

Sornchangwat, P., Thammateeradaycho, N., \& Ramirez, M. (December 17, 2020). Thailand: Impact Of COVID-19 on Commercial Contracts in Thailand: Force Majeure. Tilleke \& Gibbins. In https://www.mondaq.com/operational-impactsand-strategy/1017616/impact-of-covid-19-on-commercial-contracts-inthailand-force-majeure.

Stott, C., West, O., \& Harrison, M. (2020). A Turning Point, Securitization, and Policing in the Context of Covid-19: Building a New Social Contract Between State and Nation? Policing: A Journal of Policy and Practice, 1, 1-21. doi: 10.1093/police/paaa021.

Sukha, Yu. S. (2016). Rules on hardship (substantial change of circumstances): a comparative analysis of the provisions of the DCFR, UNIDROIT, the civil legislation, and judicial practice of Ukraine. Chasopys tsyvilistyky, 21, 82-87. In http://www.irbis-nbuv.gov.ua/cgibin/irbis_nbuv/cgiirbis_64.exe?C21COM=2\&I21DBN=UJRN\&P21DBN=UJR N\&IMAGE_FILE_DOWNLOAD=1\&Image_file_name=PDF/Chac_2016_21_ 19.pdf.

Sussel, I. (March 26, 2020). Coronavirus (COVID-19): Exemption from liability due to force majeure. In https://www.bakermckenzie.com/uk/insight/publications/2020/03/covid19exempt-from-liability-provisions-ukraine. 
Tan, W., Zhao, X., Ma, X., Wang, W., Niu, P., Xu, W., \& Wu, G. (2020). A novel coronavirus genome identified in a cluster of pneumonia cases. Wuhan, China 2019-2020. China CDC Weekly, 2(4), 61-62. In http://weekly.chinacdc.cn/fileCCDCW/journal/img/cover/8d108282-5bd8-49fea7df-48f6249518b1.pdf\#page $=15$.

England. Taylor v. Caldwell [1863] 3 B\&S 826 Case Summary. In https://www.lawteacher.net/cases/taylor-v-caldwell.php?vref=1.

The New York State Senate Website. (2021). Section 5-1401. Choice of law. General Obligations (GOB). In https://www.nysenate.gov/legislation/laws/GOB/5-1401

The Official Website of the State of New York. (March 20, 2020). Governor Cuomo Signs the 'New York State on PAUSE' Executive Order. Governor Andrew M. Cuomo. In https://www.governor.ny.gov/news/governor-cuomo-signs-newyork-state-pause-executive-order.

Titarenko, D. (March 25, 2020). COVID-19: how can a business properly refer to quarantine as force majeure? Bulletin. In http://www.visnuk.com.ua/uk/news/100017024-covid-19-yak-biznesu-pravilnoposilatisya-na-karantin-yak-na-fors-mazhor.

Twigg-Flesner, C. (2020). The Potential of the COVID-19 Crisis to Cause Legal Disruption to Contracts and Contract Law. SSRN. In https://ssrn.com/abstract=3625004.

Ukraine. Commercial Court of Appeal. (2011). Resolution 18/90-39/268. In https://reyestr.court.gov.ua/Review/14422497.

Ukraine. (1997). On chambers of commerce and industry in Ukraine: Law 671/97-BP. In https://zakon.rada.gov.ua/laws/show/671/97-\%D0\%B2\%D1\%80\#n118.

Ukraine. (2003). Civil Code of Ukraine. In https://zakon.rada.gov.ua/laws/show/43515\#Text.

Ukraine. (2003). Commercial Code of Ukraine. In https://zakon.rada.gov.ua/laws/show/436-15\#Text.

Ukraine. (2009). On the prevention of the spread of influenza type A / H1N1 / California / 04/09 and acute respiratory diseases among the population. Resolution 1152. In https://ips.ligazakon.net/document/view/KP091152?an=48\&ed=2010_09_08.

Ukraine. (2020) On amendments to some legislative acts of Ukraine aimed at providing additional social and economic guarantees in connection with the spread of coronavirus disease (Covid-19): Law 540-IX. In https://zakon.rada.gov.ua/laws/show/540-20.

Ukraine. (2020). On amendments to certain legislative acts of Ukraine aimed at preventing the occurrence and spread of coronavirus disease (Covid-19): Law 530-IX. In In https://zakon.rada.gov.ua/laws/show/530-20.

Ukraine. (2020). On the establishment of quarantine and the introduction of restrictive anti-epidemic measures to prevent the spread of acute respiratory disease COVID-19 caused by the coronavirus SARS-CoV-2 in Ukraine: Resolution 1236. In https://ips.ligazakon.net/document/view/kp201236?an=2. 
Ukraine. Cabinet of Ministers of Ukraine. (2009). On the prevention of the spread of influenza type A / H1N1 / California / 04/09 and acute respiratory diseases among the population: Resolution 1152. In https://ips.ligazakon.net/document/view/KP091152?an=48\&ed=2010_09_08.

Ukraine. Cabinet of Ministers of Ukraine. (2020). On the establishment of quarantine and the introduction of restrictive anti-epidemic measures to prevent the spread of acute respiratory disease COVID-19 caused by the coronavirus SARS-CoV-2 in Ukraine: Resolution 1236. In https://ips.ligazakon.net/document/view/kp201236?an=2.

Ukraine. Kyiv Commercial Court of Appeal. (2011). Resolution 18/90-39/268. In https://reyestr.court.gov.ua/Review/14422497.

Ukraine. Supreme Court. (2012). Resolution 6-93uc11. In https://verdictum.ligazakon.net/document/23069464.

United Arab Emirates. (1985). On the Civil Transactions: Law 5. In https://legaladviceme.com/legislation/126/uae-federal-law-5-of-1985-on-civiltransactions-law-of-united-arab-emirates

United Nations. (1980). Convention on Contracts for the International Sale of Goods. In https://uncitral.un.org/en/texts/salegoods/conventions/sale_of_goods/cisg.

United States. Gulf Oil Corp. v. F.E.R.C. Court of Appeals. Apr 21, 1983. 706 F.2d 444 (3d Cir. 1983).

United States. Cater v. Barker. North Carolina Court of Appeals. Aug 1, 2005. 172 N.C. App. 441 (N.C. Ct. App. 2005).

United States. Blount-Midyette v. Aeroglide Corp. Supreme Court of North Carolina. Apr 1, 1961. 119 S.E.2d 225 (N.C. 1961).

Wu, F., Zhao, S., Yu, B., Chen, Y., Wang, W., Song, Z., Hu, Y., Tao, Z.-W., Tian, J.-Y., Pei, Y.-Y., Yuan, M.-L., Zhang, Y.-L., Dai, F.-H., Liu, Y., Wang, Q.-M., Zheng, J.-J., Xu, L., Holmes, E.C., \& Zhang, Y. (2020). A new coronavirus associated with human respiratory disease in China. Nature, 579 (7798), 265 269. doi: 10.1038/s41586-020-2008-3.

Xiong, J., Lipsitz, O., Nasri, F., Lui, L., Gill, H., Phan, L., Chen-Li, D., Lacobucci, M., Ho, R., Majeed, A., \& McIntyre, R. (2020). Impact of COVID-19 pandemic on mental health in the general population: A systematic review. Journal of Affective Disorders, 277, 55-64. doi: 10.1016/j.jad.2020.08.001.

Zakirova, S. (2020). Force majeure: What has the COVID-19 virus pandemic changed? Public opinion on lawmaking, 5(190), 4-10. In http://nbuviap.gov.ua/images/dumka/2020/5.pdf.

Zhu, N., Zhang, D., Wang, W., Li, X., Yang, B., Song, J., Zhao, X., Huang, B., Shi, W., Lu, R., Niu, P., Zhan, F., Ma, X., Wang, D., Xu, W., Wu, G., Gao, G.F., \& Wenjie, T. (2020). A Novel Coronavirus from Patients with Pneumonia in China, 2019. The New England Journal of Medicine, 382(8), 727-733. doi: 10.1056/NEJMoa2001017. 